\title{
URBAN HEAT ISLAND INTENSITY OF ZAGREB IN SUMMER AND WINTER SEASON
}

DOI: http://dx.doi.org/10.18509/GBP.2018.01

UDC: 551.508.951:551.583.13(497..521.2)

\author{
Mladen Maradin \\ Anita Filipčić \\ Department of Geography, Faculty of Science, University of Zagreb, Croatia
}

\begin{abstract}
The urban heat island (UHI) marks an area of higher temperature in the city compared to the non-urban surroundings. It is mostly caused by thermal properties of urban materials that easily absorb heat, but there are many other factors contributing to it. The UHI intensity is defined as the difference in spatially averaged temperature between urban area and non-urban surroundings. In the annual course UHI intensity is most pronounced in the cold part of the year. UHI intensity analyses was carried out using the data of seven meteorological and climatological stations in the city of Zagreb and surrounding area. The period of analyses was 1995-2014, which is the longest time series available for all stations. UHI intensity in the city of Zagreb was determined using average, minimum and maximum daily temperatures for summer and winter season. Additionally, the analyses for July and January, the warmest and coldest months in annual course of temperature respectively, were carried out. The occurrence of UHI intensity was also analysed since it was expected that differences in temperature would be highest in winter and in January. Higher temperatures in the stations in the city compared to the non-urban surroundings, especially in the cold part of the year, confirms the existence of a UHI. The variations and its causes in UHI intensity between different parts of the city of Zagreb was researched in the paper. Also, the impact of UHI on the increase of temperature in Zagreb was determined, where the highest temperature increase is expected in the stations in the city center.
\end{abstract}

Keywords: urban heat island, UHI intensity, daily temperature, Zagreb

\section{INTRODUCTION}

The urban heat island (UHI) marks an area of higher temperature in the city compared to the non-urban surroundings that has been confirmed by many studies [1], [2], [3] and [4]. There are number of factors that contributing to the UHI, but the most important are urban materials, anthropogenic heat (heating, industry, cars) and atmospheric pollution [5]. The $\mathrm{UHI}$ is also result of multiple reflection of short wave radiation within street canyons, decrease of albedo of urban surfaces, decrease of total turbulent heat transport due to wind speed reduction in the urban areas that result in altered energy balance that lead to a positive thermal anomaly [6].

The UHI intensity is defined as difference in spatially averaged temperature between urban area and non-urban surroundings [2], [4], [7] and [8]. It depends on several factors - size of the city, topography, features of the surface [5]. Part of a day or a season have a great impact on UHI intensity, since the phenomenon is strong over a night and in winter [7], [9] and [10]. The synoptic conditions also make great impact; when the atmosphere 
is cloudless and there are light winds conditions, the UHI intensity is strong [7] and [11]. Therefore, strong UHI can develop under anticyclone conditions with clear skies and calm weather without precipitation, while cyclone conditions allow the development of weak UHI or even prevent their formation [8]. Finally, the emission of anthropogenic heat affects the UHI intensity but its impact is weaker and it depends on the season [7].

There are lots of researches that deals with UHI, but they are not homogeneous in time and space, and the results must be compared with a caution due to different methods and techniques used [8]. Most studies cover short periods of time [1], and deal with detecting the UHI itself or study its relationship to other meteorological parameters. An overview of UHI studies in the Europe in last two decades were given by Santamouris [12].

There are papers that deals with temperature time series analyses for Zagreb and some of them indicate the existence of UHI phenomenon in Zagreb. Some of this papers are [13], [14], [15], [16], [17], [18], [19], [20] and [21]. In most studies the UHI phenomenon in Zagreb were detected using just few stations and short time series or were studied in relation to climate change impact.

The aim of this paper is to determine existence and intensity of UHI in Zagreb using available data from meteorological stations in the city and its non-urban surrounding. Average, average minimum and average maximum temperatures for the summer and winter season, as well as July and January will be analysed.

\section{DATA AND METHODS}

In order to analyse the urban heat island intensity of Zagreb, the data for seven meteorological or climatological stations in the Zagreb urban area and its surroundings were used (tab. 1, fig. 1).

Table 1. Geographical features of researched meteorological stations

\begin{tabular}{|l|l|l|l|l|}
\hline station & lon & lat & alt $(\mathrm{m})$ & local climate zone \\
\hline Zagreb - airport & $16^{\circ} 04^{\prime} \mathrm{E}$ & $45^{\circ} 44^{\prime} \mathrm{N}$ & 106 & Low plants \\
\hline Zagreb - Botinec & $15^{\circ} 57^{\prime} \mathrm{E}$ & $45^{\circ} 45^{\prime} \mathrm{N}$ & 116 & Sparsely built \\
\hline Zagreb - Grič & $15^{\circ} 59^{\prime} \mathrm{E}$ & $45^{\circ} 49^{\prime} \mathrm{N}$ & 157 & Compact midrise \\
\hline Zagreb- Maksimir & $16^{\circ} 02^{\prime} \mathrm{E}$ & $45^{\circ} 49^{\prime} \mathrm{N}$ & 123 & Low plants/Large low-rise \\
\hline Zagreb - Rim & $16^{\circ} 00^{\prime} \mathrm{E}$ & $45^{\circ} 50^{\prime} \mathrm{N}$ & 220 & Open low-rise \\
\hline Puntijarka & $15^{\circ} 58^{\prime} \mathrm{E}$ & $45^{\circ} 55^{\prime} \mathrm{N}$ & 988 & Dense trees \\
\hline Šibice & $15^{\circ} 47^{\prime} \mathrm{E}$ & $45^{\circ} 51^{\prime} \mathrm{N}$ & 133 & Low plants \\
\hline
\end{tabular}

In order to include all available stations in the Zagreb city area in analyses the 20 -year period (1995-2014) was used. The reason for the chosen period is the duration of measurement on the stations used. The measurement at Šibice station has started at July 1995 and at Zagreb-Botinec station measurement has ended in 2015. Although the period is considerably shorter than recommended 30 -year period, it is long enough since the temperature is not as variable as some other climatic elements.

The environment in which the analysed stations are located were described using the Local Climate Zone (LCZ) approach, that is proposed by Stewart and Oke [22] (tab. 1). The main disadvantage of the spatial distribution of the stations for the UHI intensity analyses is that there is no station in dense built city center. Zagreb-Grič is the station that is situated closest to city center, but there are several reasons why even higher temperature can be expected in that part of the city. This station is of historical significance (uninterrupted measurements from 1862), but the thermometer of this station is at the 
height of first floor (significantly higher than $2 \mathrm{~m}$ ) and it is oriented toward north [34]. Also, the courtyard where the station is placed is oriented toward nearby park. Therefore, the lower temperatures in this stations can be expected than classification within Compact midrise can suggest. Furthermore, the Zagreb-Grič station is situated on the higher part of the city (Upper town) that is about 30 meters higher then densely build part of city center (Lower city). If there were station in the Lower city of Zagreb the higher temperatures would be measured that would result in stronger UHI intensity, than it is determined in by this research.

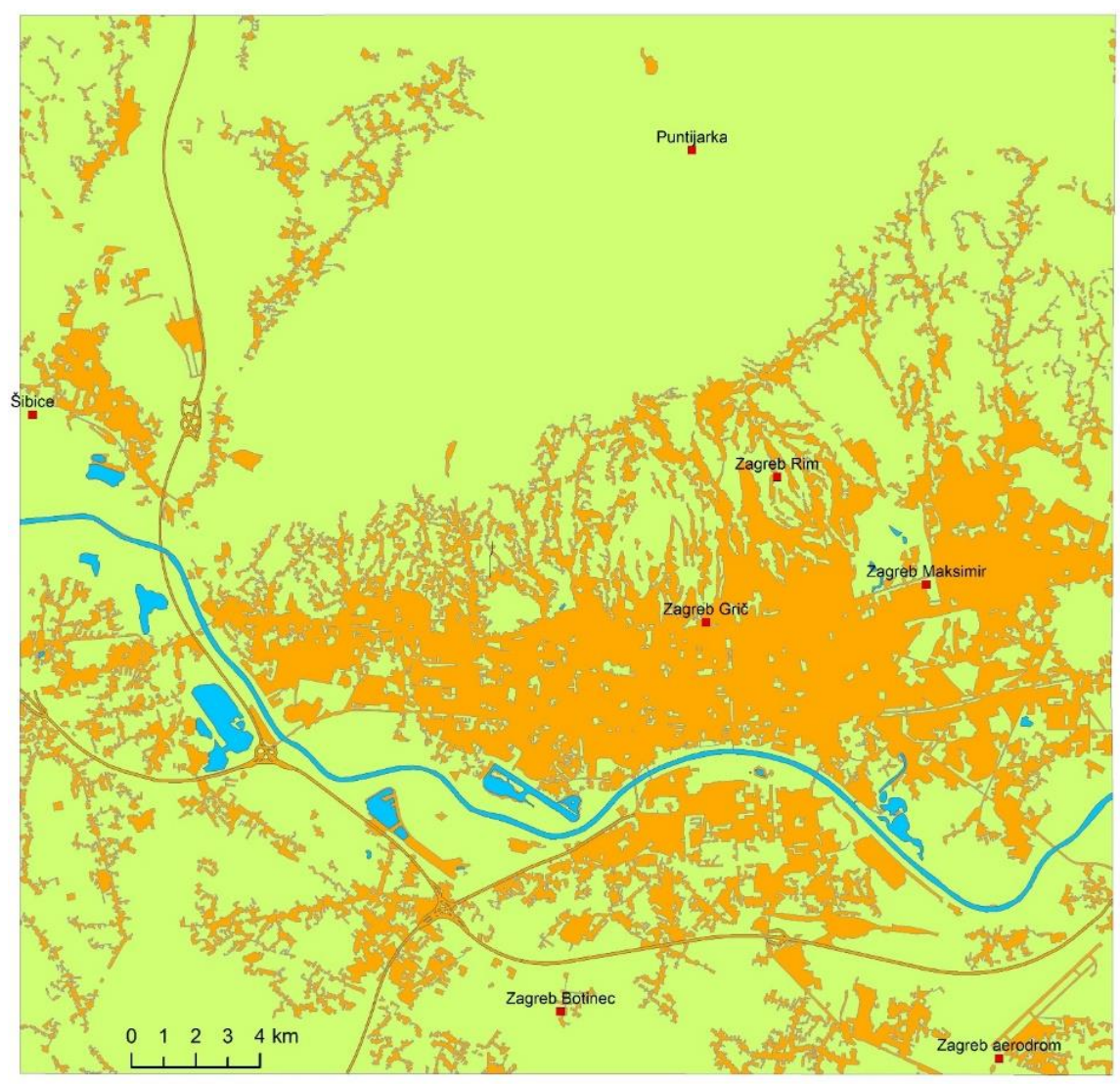

Figure 1. Geographical distribution of the researched meteorological stations. Orange color mark the built-up areas.

The dual LCZ classification of the Zagreb-Maksimir station as Low plants/Large low-rise has to be explained. Although the station is mostly surrounded by the low plants, on the western side of that station there are small industrial area and in 1993 the additional tennis court has been built near the measuring field [23], that has influenced on the representativeness of the measured data in research period. Therefore, the temperatures in that station can be somewhat higher than the proposed local climatic zone can suggest. Also, all analysed stations are meteorological stations, so the data are measured for the purpose of weather forecast and not for determination of the UHI, but in lack of other meteorological data, the data from existing stations were used.

The average, average minimum and average maximum temperatures were used to analyse UHI intensity. The data were obtained from Croatian Meteorological and Hydrological Service in Zagreb. There were missing data in the data series - Šibice (January-June 1995), Zagreb-Rim (March and April 2010), Zagreb-Botinec (October 2002 - average temperature), Šibice (June 2013 - maximum temperature and September 2014 - 
minimum temperature). The missing data were interpolated using the data of nearest station (Zagreb-Grič). Thereby the formula $B_{i}=A_{i}+1 / n \sum\left(B_{j}-A_{j}\right)$ was used, where the $B_{i}$ is missing monthly average, the $A_{i}$ monthly average of nearest station for the same month and $B_{j}-A_{j}$ are differences of all available pairs of data for both stations.

UHI intensity is difference between the temperature of city center and their less built-up surroundings [12]. Therefore, to analyse the UHI intensity the differences, $\Delta \mathrm{T}_{\mathrm{u}-\mathrm{r}}=\mathrm{T}_{\mathrm{u}}-\mathrm{T}_{\mathrm{r}}$ (where $T_{u}$ is temperature of urban area and $T_{r}$ is temperature of rural area) has to be calculated. Ideally, an urban heat island is the temperature of a given location in the city subtracted from the temperature that would be measured at that same location without the presence of the city. Since such a measurement is not possible, the UHI intensity can be approximated by calculating the simultaneous temperature difference between an urban center and any nearby rural location with similar geographic features. This method is used for determining the intensity and detailed features of the heat island, but the results obtained by that way must be compared to other researches with caution [2]. The statistical significance of the differences was tested by the Student's paired t-test. The significance of the trends was determined by Mann-Kendal trend test. Both significances were calculated for $\alpha=0,05$.

To determine the UHI existence and intensity differences for average, average minimum and average maximum temperature were calculated. Since the effects of urban heat island are easily detectible at minimum temperatures [5] the differences were calculated for warmest and coldest seasons and months - summer and winter; and July and January. Greater differences in winter and January would confirm existence of UHI.

\section{RESULTS AND DISCUSSION}

\section{Features of urban heat island in Zagreb}

The annual course of temperatures (average, average minimum and average maximum) of all researched stations has minimum in January and maximum in July (fig. 2). It is continentally influenced annual course typical for mid-latitude. Only exception is the annual course of average maximum temperature in Puntijarka that has maximum in August rather than in July. The comparison of annual course of average minimum and average maximum temperature (fig. 2) indicate that deviations are more pronounced in the case of minimum temperature that confirms existence of UHI.

As it is expected the highest average annual temperature has been obtained for the ZagrebGrič station that is situated in city center (tab. 2). The average annual temperatures of the other stations are lower. Significantly lower temperature in Puntijarka is the result of high altitude of that station (tab. 1). The same goes for average minimum temperature. The average maximum temperature is highest in the Zagreb-Botinec station, which is situated in rural surrounding of the Zagreb (Sparsely built LCZ). Temperatures in this station is also higher than in nearby Zagreb-airport station that has similar surroundings.

To detect the UHI intensity the average minimum temperatures are more relevant, so the Zagreb-Grič station could be good representative of the station in the city center. This can be additionally confirmed by calculating mutual differences of the stations average (minimum and maximum) annual temperatures (tab. 3). Differences are similar for the average annual and average minimum temperatures. Differences have highest value for the Zagreb-Grič and then for Zagreb-Rim station. Stations located further away from city center and in sparsely built environments have lover values of differences (ZagrebBotinec, Zagreb-Maksimir, Zagreb-airport). The lowest differences are obtained for the 
Šibice and Puntijarka, stations in rural surroundings of Zagreb. The values of the average minimum temperature differences are higher than a differences of average temperatures, that confirms the fact that the UHI intensity is more pronounced for the minimum temperatures. Also, almost all differences of the average minimum temperatures (except Zagreb-Maksimir and Zagreb-Botinec), in contrast of differences of average maximum temperatures, are statistically significant (tab. 3), proving that minimum temperatures are good indicator of UHI intensity.

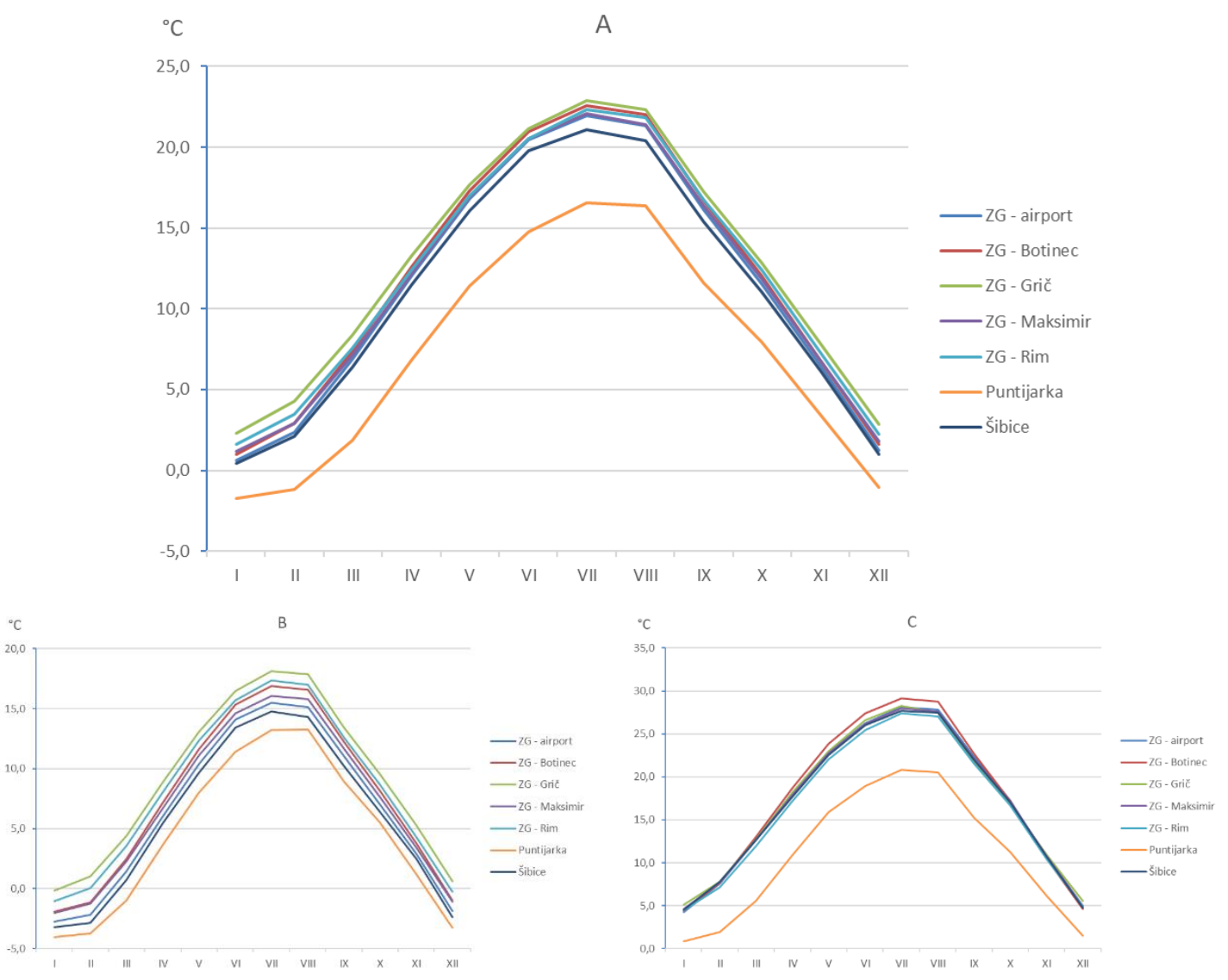

Figure 2. Annual course of average (A), average minimum

(B) and average maximum (C) temperature in Zagreb, 1995 - 2014

Table 2. Average, average minimum, average maximum annual temperature for meteorological stations in Zagreb, $1995-2014\left({ }^{\circ} \mathrm{C}\right)$

\begin{tabular}{|l|c|c|c|}
\hline & ave. temp. & ave. min. temp. & ave. max. temp. \\
\hline ZG - airport & 11.5 & 6.4 & 16.9 \\
\hline ZG - Botinec & 12.0 & 7.5 & 17.3 \\
\hline ZG - Grič & 12.8 & 9.0 & 17.0 \\
\hline ZG - Maksimir & 11.8 & 7.1 & 16.9 \\
\hline ZG - Rim & 12.1 & 8.2 & 16.3 \\
\hline Puntijarka & 7.2 & 4.4 & 10.8 \\
\hline Šibice & 10.9 & 5.8 & 16.7 \\
\hline
\end{tabular}


Table 3. Mutual differences of average (A), average minimum (B) and average maximum (C) annual temperature for meteorological stations in Zagreb for 1995-2014 period $\left({ }^{\circ} \mathrm{C}\right)$

(A)

\begin{tabular}{|l|l|l|l|l|l|l|l|}
\hline average & ZG-airport & ZG-Bot. & ZG-Grič & ZG-Maks. & ZG-Rim & Puntijarka & Šibice \\
\hline ZG-airport & $\sim$ & $0.5^{*}$ & $1.3^{*}$ & 0.3 & $0.6^{*}$ & $-4.3^{*}$ & $-0.5^{*}$ \\
\hline ZG-Bot. & $-0.5^{*}$ & $\sim$ & $0.8^{*}$ & -0.2 & 0.1 & $-4.8^{*}$ & $-1.0^{*}$ \\
\hline ZG-Grič & $-1.3^{*}$ & $-0.8^{*}$ & $\sim$ & $-1.0^{*}$ & $-0.6^{*}$ & $-5.5^{*}$ & $-1.8^{*}$ \\
\hline ZG-Maks. & -0.3 & 0.2 & $1.0^{*}$ & $\sim$ & 0.4 & $-4.5^{*}$ & $-0.8^{*}$ \\
\hline ZG-Rim & $-0.6^{*}$ & -0.1 & $0.6^{*}$ & -0.4 & $\sim$ & $-4.9^{*}$ & $-1.2^{*}$ \\
\hline Puntijarka & $4.3^{*}$ & $4.8^{*}$ & $5.5^{*}$ & $4.5^{*}$ & $4.9^{*}$ & $\sim$ & $3.7^{*}$ \\
\hline Šibice & $0.5^{*}$ & $1.0^{*}$ & $1.8^{*}$ & $0.8^{*}$ & $1.2^{*}$ & $-3.7^{*}$ & $\sim$ \\
\hline
\end{tabular}

(B)

\begin{tabular}{|l|l|l|l|l|l|l|l|}
\hline ave. min. & ZG-airport & ZG-Bot. & ZG-Grič & ZG-Maks. & ZG-Rim & Puntijarka & Sibice \\
\hline ZG-airport & $\sim$ & $1.1^{*}$ & $2.6^{*}$ & $0.7^{*}$ & $1.8^{*}$ & $-2.0^{*}$ & $-0.6^{*}$ \\
\hline ZG-Bot. & $-1.1^{*}$ & $\sim$ & $1.5^{*}$ & -0.4 & $0.7^{*}$ & $-3.1^{*}$ & $-1.8^{*}$ \\
\hline ZG-Grič & $-2.6^{*}$ & $-1.5^{*}$ & $\sim$ & $-2.0^{*}$ & $-0.9^{*}$ & $-4.6^{*}$ & $-3.3^{*}$ \\
\hline ZG-Maks. & $-0.7^{*}$ & 0.4 & $2.0^{*}$ & $\sim$ & $1.1^{*}$ & $-2.6^{*}$ & $-1.3^{*}$ \\
\hline ZG-Rim & $-1.8^{*}$ & $-0.7^{*}$ & $0.9^{*}$ & $-1.1^{*}$ & $\sim$ & $-3.8^{*}$ & $-2.4^{*}$ \\
\hline Puntijarka & $2.0^{*}$ & $3.1^{*}$ & $4.6^{*}$ & $2.6^{*}$ & $3.8^{*}$ & $\sim$ & $1.3^{*}$ \\
\hline Šibice & $0.6^{*}$ & $1.8^{*}$ & $3.3^{*}$ & $1.3^{*}$ & $2.4^{*}$ & $-1.3^{*}$ & $\sim$ \\
\hline
\end{tabular}

(C)

\begin{tabular}{|l|l|l|l|l|l|l|l|}
\hline ave. max. & ZG-airport & ZG-Bot. & ZG-Grič & ZG-Maks. & ZG-Rim & Puntijarka & Šibice \\
\hline ZG-airport & $\sim$ & 0.5 & 0.2 & 0.0 & -0.5 & $-6.1^{*}$ & -0.1 \\
\hline ZG-Bot. & -0.5 & $\sim$ & -0.3 & -0.5 & $-1.0^{*}$ & $-6.5^{*}$ & -0.6 \\
\hline ZG-Grič & -0.2 & 0.3 & $\sim$ & -0.2 & $-0.7^{*}$ & $-6.2^{*}$ & -0.3 \\
\hline ZG-Maks. & 0.0 & 0.5 & 0.2 & $\sim$ & -0.5 & $-6.1^{*}$ & -0.1 \\
\hline ZG-Rim & 0.5 & $1.0^{*}$ & $0.7^{*}$ & 0.5 & $\sim$ & $-5.5^{*}$ & 0.4 \\
\hline Puntijarka & $6.1^{*}$ & $6.5^{*}$ & $6.2^{*}$ & $6.1^{*}$ & $5.5^{*}$ & $\sim$ & $5.9^{*}$ \\
\hline Šibice & 0.1 & 0.6 & 0.3 & 0.1 & -0.4 & $-5.9^{*}$ & $\sim$ \\
\hline
\end{tabular}

*significant at level $\alpha=0,05$

Analyses of annual average maximum temperatures differences gives rather different result. The differences are highest for the Zagreb-Botinec station, which is expected since this station has highest average maximum annual temperature. The annual average maximum temperature for the Zagreb-Grič is for $0,3{ }^{\circ} \mathrm{C}$ lower than in Zagreb-Botinec, but the difference is not statistically significant. Differences of annual average maximum temperatures is similar for the Zagreb-Maksimir and Zagreb-airport station. That can be caused by influence of uniformly warming of the Sava valley area in the period of maximum temperatures. The Zagreb-Botinec is also located in the Sava valley, but in that station average maximum temperatures are significantly higher, that could indicate that additional microclimate factors influence the warming of the station. Other stations are on the higher elevation or are more distant form the city so the temperatures are lower and therefore the UHI effect is reduced. The highest station in the urban area is Zagreb- 
Rim and that is the cause of relatively low temperatures despite the UHI effect. The average maximum temperature measured in Zagreb-Rim is lower than in Šibice station.

\section{Urban heat island intensity}

UHI intensity is calculated using season (summer and winter) and monthly (January and July) average temperatures (tab 4.). Generally, the UHI intensity is stronger in winter and January than in summer and July. The exception is Puntijarka where the UHI intensity is stronger in summer and winter. This is due to synoptic situation that is common for the Zagreb during the winter. Zagreb is located in Sava valley, where the temperature inversion is usual in winter months. Low clod cover and fog block the Sun radiation in the city center while the Puntijarka on the sunward slopes of the Medvednica has more clear sky and receive more Sun radiation. Therefore, the difference of the temperatures between Puntijarka and Zagreb-Grič is larger in summer than in winter.

Table 4. UHI intensity based on average (A), average minimum (B) and average maximum (C) temperatures in summer, winter, July and January in Zagreb for 1995-2014 period $\left({ }^{\circ} \mathrm{C}\right)$.

\begin{tabular}{|l|c|c|c|c|}
\hline average & summer & winter & July & January \\
\hline ZG-airport & -0.9 & -1.7 & -0.9 & -1.7 \\
\hline ZG-Botinec & -0.3 & -1.3 & -0.3 & -1.3 \\
\hline ZG-Maksimir & -0.8 & -1.2 & -0.8 & -1.1 \\
\hline ZG-Rim & -0.6 & -0.7 & -0.6 & -0.6 \\
\hline Puntijarka & -6.2 & -4.5 & -6.3 & -4.0 \\
\hline Šibice & -1.7 & -2.0 & -1.8 & -1.8 \\
\hline
\end{tabular}

(B)

\begin{tabular}{|l|c|c|c|c|}
\hline ave. min. & summer & winter & July & January \\
\hline ZG-airport & -2.6 & -2.8 & -2.6 & -2.6 \\
\hline ZG-Botinec & -1.2 & -1.9 & -1.2 & -1.8 \\
\hline ZG-Maksimir & -2.0 & -1.9 & -2.0 & -1.8 \\
\hline ZG-Rim & -0.8 & -0.9 & -0.8 & -0.9 \\
\hline Puntijarka & -4.9 & -4.2 & -4.9 & -3.9 \\
\hline Šibice & -3.3 & -3.3 & -3.4 & -3.0 \\
\hline
\end{tabular}

\begin{tabular}{|l|c|c|c|c|}
\hline ave. max. & summer & winter & July & January \\
\hline ZG-airport & -0.1 & -0.6 & -0.2 & -0.8 \\
\hline ZG-Botinec & 1.0 & -0.6 & 0.9 & -0.7 \\
\hline ZG-Maksimir & -0.2 & -0.4 & -0.4 & -0.5 \\
\hline ZG-Rim & -0.8 & -0.7 & -0.9 & -0.7 \\
\hline Puntijarka & -7.4 & -4.7 & -7.5 & -4.3 \\
\hline Šibice & -0.4 & -0.5 & -0.6 & -0.6 \\
\hline
\end{tabular}

In the winter and January, according to the calculated UHI intensity, the warmest stations are, after Zagreb-Grič; Zagreb-Rim, Zagreb-Maksimir and Zagreb-airport. Temperatures decrease proportionally with the distance from the city center, but the impact of the different station surroundings has to be taken into account. Šibice station, that are far 
away from the direct influence of UHI effect, has the lowest temperature (except the Puntijarka station). In the case of average maximum temperature, the Zagreb-Maksimir is warmest station (after the Zagreb-Grič), but the values of UHI intensity are not that pronounced as for average and average minimum temperatures. This is to be expected since the maximum temperature is not best indicator of UHI intensity.

During the summer and July, the warmest station besides the Zagreb-Grič station is Zagreb-Botinec, and then Zagreb-Rim or Zagreb-airport, Zagreb-Maksimir and Šibice for the average and average maximum temperatures. Zagreb-Botinec has highest average maximum temperatures, even higher than Zagreb-Grič station.

The values of UHI intensity are highest for the average minimum temperatures (tab. 4). Furthermore, values of average minimum temperatures are similar for the all observed seasons and months, that confirms that at the minimum temperatures the UHI effect is most easily detected. For the average and average maximum temperatures the UHI intensity is stronger in winter and January than in summer and July.

If stations in the urban and semiurban area of the city of Zagreb are analysed (i.e. without stations Puntijarka and Šibice) then the maximum of UHI intensity in the annual course is up to $2,8^{\circ} \mathrm{C}$. This is similar to the results obtained in the related studies of similar cities [1], [3] and [5], but less than value that can be estimated using formula for UHI intensity in European cities [24]. Due to the mentioned disadvantages in the distribution of the stations the potential UHI intensity in Zagreb is expected to be larger. Further researches are necessary as well as placement of net of automatic meteorological stations for more detailed analyses of UHI intensity in Zagreb. This future measurement could show that the temperatures in the city center of Zagreb could be higher than those measured in Zagreb-Grič so far. Therefore, the UHI intensity in Zagreb could have higher values, but that remain to be determined in future researches.

\section{Trend analyses of temperature change}

UHI intensity depends on features of local climates zones where the particular station is located. Any changes in nearby surroundings can lead to changes in temperature features, i.e. increase or, more rarely, decrease of temperature. Therefore, the trend analyses of the 20-years period for the researched stations were carried out (tab. 5). These changes could indicate the changes in the surroundings of the stations, but the general climate change (rise in temperature), independent from the microclimatic variations, must be taken into account.

There is general trend of temperature increase in Zagreb in the second half of $20^{\text {th }}$ century [19], [20], [21]. Statistically significant increase in temperature has been determined for most of the annual, summer and July values of average, average minimum and average maximum temperatures. None of the winter and January increase in temperature were statistically significant. Lowest trend of rise in temperature has the stations outside of the city of Zagreb - Šibice and Puntijarka. Increase of temperature is relatively small in Zagreb-Rim, while other stations within the Zagreb city area have larger trend of increase of temperature than mentioned stations. The decrease of average maximum temperature in winter were determined only for Puntijarka station and it is not significant.

The highest increase in average maximum temperature is determined for the ZagrebBotinec station for the annual values, summer and July (tab. 5). These increases are statistically significant. Such high value of temperature increase trend can explain the high temperature in this station in the summer and July. Since other stations have lower trends of temperature increase, increase in Zagreb-Botinec station can be caused by 
changes in microclimate features of the station surroundings. Changes in land use may significantly impact energy balance of the atmosphere and can lead to warming especially in warm part of the year. Since the station is surrounded by the agriculture areas such changes can be the cause. To confirm this assumption further analyses of land use change for this station has to be carried out.

Table 5. Trend slopes of average (A), average minimum (B) and average maximum (C) temperatures for meteorological stations in Zagreb for 1995-2014 $\left({ }^{\circ} \mathrm{C} /\right.$ year $)$

(A)

\begin{tabular}{|l|c|c|c|c|c|}
\hline average & annual & summer & winter & July & January \\
\hline ZG-airport & $0.06575^{*}$ & $0.07055^{*}$ & 0.05348 & $0.09639^{*}$ & 0.10835 \\
\hline ZG-Botinec & $0.09279^{*}$ & $0.10922^{*}$ & 0.05774 & $0.13180^{*}$ & 0.11113 \\
\hline ZG-Grič & $0.07489^{*}$ & $0.08414^{*}$ & 0.05677 & $0.11406^{*}$ & 0.12301 \\
\hline ZG-Maksimir & $0.07287^{*}$ & $0.08243^{*}$ & 0.05506 & $0.11301^{*}$ & 0.11301 \\
\hline ZG-Rim & $0.05951^{*}$ & 0.05203 & 0.04644 & 0.07789 & 0.10932 \\
\hline Puntijarka & $0.05899^{*}$ & $0.07293^{*}$ & 0.01291 & $0.09722^{*}$ & 0.05699 \\
\hline Šibice & $0.06790^{*}$ & $0.06892^{*}$ & 0.06033 & $0.10218^{*}$ & 0.11338 \\
\hline
\end{tabular}

(B)

\begin{tabular}{|l|c|c|c|c|c|}
\hline ave. min. & annual & summer & winter & July & January \\
\hline ZG-airport & $0.06862^{*}$ & $0.05348^{*}$ & 0.06479 & 0.07346 & 0.07692 \\
\hline ZG-Botinec & $0.08616^{*}$ & $0.08346^{*}$ & 0.07734 & $0.10564^{*}$ & 0.10353 \\
\hline ZG-Grič & $0.06944^{*}$ & $0.06075^{*}$ & 0.06794 & $0.08932^{*}$ & 0.11271 \\
\hline ZG-Maksimir & $0.05578^{*}$ & 0.03977 & 0.05815 & 0.06000 & 0.08850 \\
\hline ZG-Rim & $0.06631^{*}$ & $0.05023^{*}$ & 0.06409 & 0.07556 & 0.10519 \\
\hline Puntijarka & $0.07848^{*}$ & $0.08446^{*}$ & 0.04712 & $0.11023^{*}$ & 0.08526 \\
\hline Šibice & $0.07513^{*}$ & $0.05694^{*}$ & 0.07855 & 0.08068 & 0.08992 \\
\hline
\end{tabular}

(C)

\begin{tabular}{|l|c|c|c|c|c|}
\hline ave. max & annual & summer & winter & July & January \\
\hline ZG-airport & 0.06527 & $0.08474^{*}$ & 0.04434 & $0.10699^{*}$ & 0.14060 \\
\hline ZG-Botinec & $0.10734^{*}$ & $0.17291^{*}$ & 0.03521 & $0.19180^{*}$ & 0.13414 \\
\hline ZG-Grič & $0.07972^{*}$ & $0.11393^{*}$ & 0.03915 & $0.14511^{*}$ & 0.12947 \\
\hline ZG-Maksimir & 0.06701 & $0.08013^{*}$ & 0.04060 & $0.11759^{*}$ & 0.13023 \\
\hline ZG-Rim & 0.06252 & 0.06404 & 0.04256 & 0.09383 & 0.13256 \\
\hline Puntijarka & 0.04373 & $0.07754^{*}$ & -0.02862 & $0.10910^{*}$ & 0.01647 \\
\hline Šibice & $0.06770^{*}$ & $0.07805^{*}$ & 0.04787 & $0.10436^{*}$ & 0.14474 \\
\hline
\end{tabular}

*significant at level $\alpha=0,05$

\section{CONCLUSION}

The analyses of UHI of the city of Zagreb were carried out for 1995-2014 period and the existence of UHI were confirmed. Zagreb-Grič station in city center is the warmest station in the Zagreb, while in Zagreb-Botinec the highest maximum temperatures were measured. Mutual differences of the stations temperatures were statistically significant for most of stations average minimum temperatures. Therefore, the UHI intensity was determined using average minimum temperatures. Highest values of UHI intensity were obtained for winter and January. Within the Zagreb urban area, the UHI intensity of 2,8 ${ }^{\circ} \mathrm{C}$ is determined. Statistically significant increase trends were determined for annual, summer and January temperatures. No significance trends were obtained for winter and 
January. Due to lack of stations in the dense built city center the placement of several measuring stations are necessary to determine the UHI intensity more precisely.

\section{REFERENCES}

[1] Kłysik K., Fortuniak K. Temporal and spatial characteristics of the urban heat island of Łodź, Poland, Atmospheric Environment, vol. 33, pp. 3885-3895, 1999.

[2] Magee N., Curtis J., Wendler G. The urban heat island effect at Fairbanks, Alaska, Theoretical and Applied Climatology, vol. 64, pp. 39-47, 1999.

[3] Pongrácz R., Bartholy J., Dezső Z. Remotely sensed thermal information applied to urban climate analysis, Advances in Space Research, vol. 37, pp. 2191-2196, 2006.

[4] Papanastasiou D., Kittas C. Maximum urban heat island intensity in a medium-sized coastal Mediterranean city, Theoretical and Applied Climatology, vol. 107(3-4), pp. 407-416, 2011.

[5] Yagüe C., Zurita E., Martinez A. Statistical analysis of the Madrid urban heat island, Atmospheric Environment B, vol. 25, pp. 327-332, 1991.

[6] Oke T.R. The energetic basis of the urban heat island, Quarterly Journal of the Royal Meteorological Society, vol. 108, pp. 1-24, 1982.

[7] Montávez J.P., Rodríguez A., Jiménez J.I. A study of the urban heat island of Granada, International Journal of Climatology, vol. 20, pp. 899-911, 2000.

[8] László E., Bottyán Z., Szegedi S. Long-term changes of meteorological conditions of urban heat island development in the region of Debrecen, Hungary, Theoretical and Applied Climatology, vol. 124, pp. 365-373, 2016.

[9] Kim Y., Baik J. Maximum urban heat island intensity in Seoul, Journal of Applied Meteorology, vol. 41, pp. 651-659, 2002.

[10] Velazquez-Lozada A., Gonzalez J.E., Winter A. Urban heat island effect analysis for San Juan, Puerto Rico, Atmospheric Environment, vol. 40, pp. 1731-1741, 2006.

[11] Szegedi S., Tóth T., Kapocska L., Gyarmati R. Examinations on the factors of urban heat island development in small and medium-sized towns in Hungary, Carpathian Journal of Earth and Environmental Sciences, vol. 8, pp. 209-214, 2013.

[12] Santamouris M. Heat island research in Europe, the state of the art, Journal of Advances in Building Energy Research, vol. 1(28), pp. 123-150, 2007.

[13] Goldberg J. Prilozi istraživanju klimatskih fluktuacija u Jugoslaviji, Radovi Geofizičkog instituta u Zagrebu, vol. 3, pp. 27, 1953.

[14] Šegota T. Sekularne fluktuacije temperature u Zagrebu, Geografski glasnik, vol. 32, pp. 3960, 1970.

[15] Juras J. Neke karakteristike promjene klime Zagreba u poslednjem tridesetljeću., Geofizika, vol. 2, pp. 93-102, 1985.

[16] Šegota T. Srednja temperatura zraka u Zagrebu, Geografski glasnik, vol. 48, pp. 13-25, 1986.

[17] Šegota T. Maksimalne temperature zraka u Zagrebu, Radovi, vol. 22, pp. 5-18, 1987.

[18] Šegota T. Minimalne temperature zraka u Zagrebu, Geografski glasnik, vol. 50, pp. 8-21, 1988.

[19] Radić V., Pasarić N., Šinik N. Analiza zagrebačkih klimatoloških nizova pomoću empirijski određenih prirodnih sastavnih funkcija, Geofizika, vol. 21(1), pp. 15-36, 2004.

[20] Ogrin, D. Long-term air temperature changes in Ljubljana (Slovenia) in comparison to Trieste (Italy) and Zagreb (Croatia), Moravian Geographical Reports, vol. 23(3), pp. 17-26, 2015. 
[21] Ogrin D., Krevs M. Assessing urban heat island impact on long-term trends of air temperatures in Ljubljana, Dela, vol. 43, pp. 41-59, 2015.

[22] Stewart I.D., Oke T. 'Local Climate Zones' for urban temperature studies, Bulletin of the American Meteorological Society, vol. 93, pp. 1879-1900, 2012.

[23] Katušin Z. Meteorološko aerološki opservatorij Zagreb-Maksimir: 1926.-1995., Bilten, vol. 3, pp. 21-24, 1995.

[24] Oke T.R. City size and the urban heat island, Atmospheric Environment, vol. 7, pp. 769779, 1973. 